\title{
DEGRADATION OF A VETERINARY PHARMACEUTICAL PRODUCT IN WATER BY ELECTRO-OXIDATION USING A BDD ANODE
}

\author{
C. ESPINOZA, N. CONTRERAS, C. BERRÍOS, R. SALAZAR* \\ Departamento de Ciencias del Ambiente, Facultad de Quimica y Biología, Universidad de Santiago de Chile, USACH, Casilla 40, Correo 33, Santiago, Chile \\ Paper submitted to be published in The Journal of The Chilean Chemical Society \\ In honor of professor $L$ J. Núñez-Vergara
}

\begin{abstract}
The electrochemical oxidation (EO) treatment in water of Fantetra, a veterinary drug widely used in Chile, and its components: oxytetracycline hydrochloride, phtalylsulfathiazole and diphenhydramine, has been carried out at constant current using a BDD/Stainless steel system. First, solutions of each drug were electrolyzed following the decay of the absorbance of each compound and total organic carbon abatement. The mineralization of the Fantetra commercial formulation was also studied. An analysis of the degradation by-products was made by high performance liquid chromatography. Thus, during the degradation of each pharmaceutical by the electrochemical oxidation process, aliphatic carboxylic acids were detected prior to their complete mineralization to $\mathrm{CO}_{2}$ and nitrogen ions, while $\mathrm{NO}_{3}^{-}$and $\mathrm{NH}_{4}^{+}$remain in the treated solution.

This is an essential preliminary step towards the applicability of the EO processes for the treatment of wastewater containing pharmaceutical compounds.
\end{abstract}

Keywords: Oxytetracycline; phthalylsulfathiazole; diphenhydramine; boron-doped diamond electrode; mineralization.

\section{INTRODUCTION}

The wide range of products of the pharmaceutical industry has attracted attention in recent years due to their adverse effects on natural organisms and possible effects on human beings, and they are classified as pollutants when found in high concentrations in water and soil. ${ }^{1}$ Different types of persistent organic pollutants (POPs) are introduced in the environment daily, coming from a variety of sources such as effluent treatment plants and others. ${ }^{2}$ In the case of pharmaceuticals the main sources are wastewater treatment plants in the pharmaceutical industry, hospitals, and farming. ${ }^{3}$

Recent studies confirm the presence of pharmaceutical products in groundwater, surface water, and even drinking water. ${ }^{4}$ For this reason, the need to find satisfactory water treatment methods became a priority for the reduction or elimination of drugs, which are defined as POPs) because their presence causes bacterial resistance. ${ }^{5,6}$

In this sense, electrochemical advanced oxidation processes (EAOPs), together with traditional oxidation methods, represent a potential way to achieve greater efficiency in the decontamination of wastewater containing organic pollutants like pharmaceuticals. ${ }^{7,8}$ The most popular EAOPs used for improving wastewater containing organic pollutants are electrochemical oxidation $(\mathrm{EO})^{9,10}$, electro-Fenton $(\mathrm{EF})^{11,12}$, electro catalysis $(\mathrm{EC}){ }^{13}$ and photoassisted systems like photoelectron-Fenton (PEF) ${ }^{14,15,16}$ and photoelectron catalysis $(\mathrm{PEC})^{13}$. Of the EAOPs, EO is actually the most widely used method because it allows the treatment of highly toxic waste, converting completely the pollutants present in it into carbon dioxide ${ }^{17-1819}$. The EO process occurs by direct reaction of pollutants present in the wastewater with physisorbed hydroxyl radicals $(\mathrm{OH})$ electrogenerated from water discharge at the anode surface $(\mathrm{M})$ :

$$
\mathrm{M}+\mathrm{H}_{2} \mathrm{O} \rightarrow \mathrm{M}(\cdot \mathrm{OH})+\mathrm{H}^{+}+\mathrm{e}^{-}
$$

The physisorbed hydroxyl radicals $\mathrm{M}(-\mathrm{OH})$ react with the pollutants to give fully oxidized reaction products such as $\mathrm{CO}_{2}$ according to the reaction

$$
a \mathrm{M}(\cdot \mathrm{OH})+\mathrm{R}+y \mathrm{e}^{-} \quad \rightarrow a \mathrm{M}+m \mathrm{CO}_{2}+n \mathrm{H}_{2} \mathrm{O}+x \mathrm{H}^{+}
$$

where $\mathrm{R}$ is an organic compound with $m$ carbon atoms. Thus, organic pollutants are completely mineralized to $\mathrm{CO}_{2}$, water and inorganic salts. For this reason, the EO method is called "electrochemical combustion". The hydroxyl radical has a high standard potential $\left(\mathrm{E}^{0}=2.80 \mathrm{~V}\right.$ vs. SHE), ensuring its fast reaction with most organics, producing dehydrogenated or hydroxylated derivatives up to conversion into $\mathrm{CO}_{2}$.

Both the electrochemical generation and chemical reactivity of heterogeneous $\mathrm{M}(\mathrm{OH})$ are dependent on the nature of the electrode material. ${ }^{20}$ Thus, a non-active anode is required for the oxygen evolution reaction, because this kind of electrode interacts very weakly with $\mathrm{OH}$. The use of a boron doped diamond (BDD) thin film in EO provides total mineralization with high current efficiency for different organics in real wastewater. ${ }^{21}$ The BDD anode is the best non-active electrode because it does not provide any catalytically active site for the adsorption of reactants and/or products in aqueous media, and for this reason it has been proposed as the preferable anode for treating organics by EO. Moreover, the BDD electrode ${ }^{22}$ has several properties such as an extremely wide potential window in aqueous and non-aqueous electrolytes, an inert surface with low adsorption properties, remarkable corrosion stability even in strongly acidic media, and extremely high $\mathrm{O}_{2}$ evolution overvoltage. ${ }^{23}$

Fantetra is a drug widely used in Chile as intrauterine tablets, serving for placenta retention in large animals such as cattle, pigs and sheep. ${ }^{24}$ The active compounds in the Fantetra capsules are oxytetracycline hydrochloride, phtalylsulfathiazole, and diphenhydramine hydrochloride. Oxytetracycline is a common antibiotic, one of ten antimicrobials licensed as growth promoters for livestock in the United States. In general, tetracyclines are the second most important group of antibiotics, both in terms of global production and use. Phthalylsulfathiazole is part of the family of sulfonamides and is medically listed as antidiarrheal or intestinal anti-infective, besides being the second most most used veterinary antibiotic in Europe..$^{25}$ Diphenhydramine hydrochloride, whose function is to act as an antihistamine, sedative and hypnotic, is used in the treatment of allergies, rhinitis, allergic conjunctivitis, and urticaria. ${ }^{26}$ The particular persistence of these pharmaceuticals in natural waters is mainly related to their low biodegradability, and they have also shown high toxicity with mutagenic and carcinogenic effects. ${ }^{6}$

For these reasons, there is great interest in the use of diverse methods with enough capability to mineralize persistent drugs in aqueous media to avoid their dangerous accumulation in the aquatic environment. Studies on the elimination of oxytetracycline hydrochloride, phtalylsulfathiazole, and diphenhydramine hydrochloride using different methods have been published in recent years. ${ }^{27-282930}$ However, there are no studies about the removal of these three drugs simultaneously or from a commercial drug.

The aim of this work was to study the electrooxidation of Fantetra at constant current density using a BDD/Steel system. Electrooxidation of each active ingredient was studied independently, and then the degradation of the drug in a mixture prepared in the laboratory and directly from the commercial formulation was also investigated. The abatement of total organic carbon in solutions of each compound and the intermediary compounds formed during the abatement process were identified and quantified.

\section{EXPERIMENTAL}

2.1. Chemicals

Oxytetracycline

hydrochloride

$((4 S, 4 \mathrm{a} R, 5 S, 5 \mathrm{a} R, 6 S, 12 \mathrm{a} S)-4-$ (dimethylamino)-3,5,6,10,11,12a-hexahydroxy-6-methyl-1,12-dioxo1,4,4a,5,5a,6,12,12a-octahydrotetracene-2-carboxamide hydrochloride, OTC), $95 \%$ purity ( Sigma-Aldrich) was used as received. Phthalylsulfathiazole 
2-(((4-[(1,3-thiazol-2-ylamino) sulfonyl) phenyl) amino) carbonyl] benzoic acid, PhSTZ 99\%, and diphenhydramine, 2-diphenyl methoxy)-N,Ndimethylamine hydrochloride, DPH $99 \%$, were supplied by Dispert S.A and were used as received. The chemical structure and some characteristics of the antibiotics studied are shown in Table 1. Fumaric, maleic, oxalic and oxamic acids were analytical grade (Sigma-Aldrich). Solutions of anhydrous sodium sulfate (analytical grade, Merck) prepared with distilled water previously deionized and with its $\mathrm{pH}$ adjusted with $1.0 \mathrm{M}$ analytical grade sulfuric acid or sodium hydroxide (both Merck) were used as supporting electrolyte. Organic solvents and other chemicals used in the analysis procedure were either HPLC or analytical grade from Merck or Sigma-Aldrich.

\subsection{Electrochemical system}

Volumes of $0.1 \mathrm{~L}$ of each pharmaceutical solution were introduced into a single compartment electrolytic cell with constant stirring at $25^{\circ} \mathrm{C}$. A BDD thin film (on $\mathrm{Si}$ ) electrode from Adamant Technologies was used as anode and an AISI 304 stainless steel plate as cathode, both $5 \mathrm{~cm}^{2}$ geometric area, with $1.0 \mathrm{~cm}$ of interelectrode gap. Solutions of each drug containing $100 \mathrm{mg} \mathrm{L}^{-1}$ of total organic carbon were prepared in $0.1 \mathrm{M} \mathrm{Na}_{2} \mathrm{SO}_{4}$ to provide enough ionic strength at $\mathrm{pH} 7.0$ were treated by $\mathrm{EO}$ at a current density (j) of $50 \mathrm{~mA} \mathrm{~cm}{ }^{-2}$, resulting in average cell voltages of $13.0( \pm 0.3) \mathrm{V}$.

Table 1. Chemical structure and characteristics of the degraded pharmaceuticals.

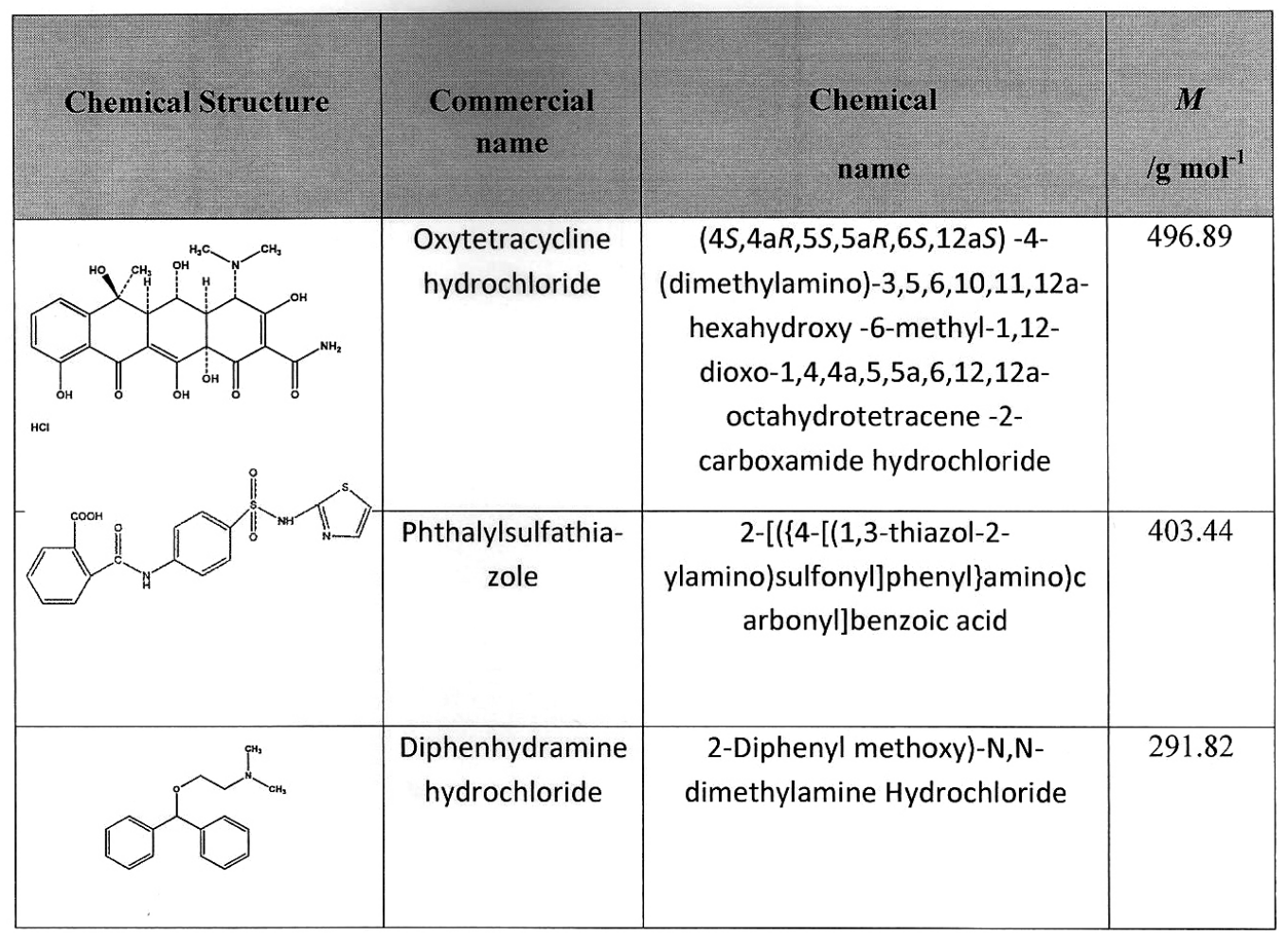

2.3. Apparatus and analytical procedures

Galvanostatic electrolyses were performed with an MCP model M10QD305 power supply which also displayed the cell voltage. The $\mathrm{pH}$ was measured with a HANA Instrument pH-meter Model HI8424. During the electrolysis, samples were withdrawn at regular time intervals from the solution kept in the cell and then refrigerated until performing the analytical procedures. The degree of mineralization was monitored from total organic carbon (TOC) determined with a Vario TOC Select (Elementar) analyzer. Reproducible TOC values with an accuracy of $\pm 1 \%$ were always found injecting $500 \mu \mathrm{L}$ aliquots in the analyzer. From these data, the mineralization current efficiency (MCE) for each treated solution was then calculated from Eq. (3):31,32

$$
\operatorname{MCE}(\%)=\left(\frac{\mathrm{n} \mathrm{F} \mathrm{V}_{\mathrm{s}} \Delta(\mathrm{TOC})_{\exp }}{4.32 \times 10^{7} \mathrm{~m} 1 \mathrm{t}} \times 100\right)
$$

where $n$ is the number of electrons consumed in the mineralization of the respective pharmaceutical, $F$ is Faraday's constant $\left(96487 \mathrm{C} \mathrm{mol}^{-1}\right), V$ is the solution volume $(\mathrm{L}), \Delta(\mathrm{TOC})_{\mathrm{exp}}$ is the experimental TOC decay $\left(\mathrm{mg} \mathrm{L}^{-1}\right)$ evaluated as the difference between the initial value and that analyzed at time $\mathrm{t}, 4.32 \square 10^{7}$ is a conversion factor $\left(3600 \mathrm{~s} \mathrm{~h}^{-1} \square 12000 \mathrm{mg} \mathrm{of} \mathrm{C} \mathrm{mol}{ }^{-1}\right), I$ is the applied current (A), $t$ is the electrolysis time (hours), and $m$ corresponds to the number of carbon atoms present in the pharmaceutical molecules, which are 22, 17 and 17 for OTC, PhSTZ and DPH, respectively. The n-values were taken according to the mineralization reactions as 104 for OTC (reaction 4), 98 for PhSTZ (reaction 5) and 92 for DPH (reaction 6), considering the complete mineralization to $\mathrm{CO}_{2}, \mathrm{SO}_{4}^{-}$and $\mathrm{NO}_{3}^{-}$ions from the following reactions:

$$
\begin{aligned}
& \mathrm{C}_{22} \mathrm{H}_{22} \mathrm{~N}_{2} \mathrm{O}_{9}+41 \mathrm{H}_{2} \mathrm{O} \rightarrow 22 \mathrm{CO}_{2}+106 \mathrm{H}^{+}+2 \mathrm{NO}_{3}^{-}+104 \mathrm{e} \\
& \mathrm{C}_{17} \mathrm{H}_{13} \mathrm{~N}_{3} \mathrm{O}_{5} \mathrm{~S}_{2}+46 \mathrm{H}_{2} \mathrm{O} \rightarrow 17 \mathrm{CO}_{2}+105 \mathrm{H}^{+}+3 \mathrm{NO}_{3}^{-}+2 \mathrm{SO}_{4}^{-}+98 \mathrm{e} \\
& \mathrm{C}_{17} \mathrm{H}_{21} \mathrm{NO}+36 \mathrm{H}_{2} \mathrm{O} \rightarrow 17 \mathrm{CO}_{2}+93 \mathrm{H}^{+}+\mathrm{NO}_{3}^{-}+92 \mathrm{e}
\end{aligned}
$$

The aliphatic carboxylic acids obtained as intermediary products were identified and quantified by ion-exclusion chromatography using a Waters 625 Chromatograph with diode array detector 2966, fitted with a Bio-Rad Aminex HPX 87H, $30 \mathrm{~cm} \times 7.8 \mathrm{~mm}$ (i.d.), column at $35^{\circ} \mathrm{C}$, at $\square=210 \mathrm{~nm}$. The mobile phase was $4 \mathrm{mM} \mathrm{H} \mathrm{SO}_{4}$ at $0.6 \mathrm{~mL} \mathrm{~min}^{-1}$. The corresponding calibration curves were constructed using pure acid samples. Absorption peaks with retention times $\left(t_{\mathrm{p}}\right)$ of $7.1 \mathrm{~min}$ for oxalic, $8.8 \mathrm{~min}$ for maleic, 10.1 min for oxamic, $15.0 \mathrm{~min}$ for fumaric, and $15.7 \mathrm{~min}$ for acetic acids were obtained in the corresponding chromatograms. Released inorganic ions were quantified by ionic chromatography by injecting $50 \mu \mathrm{L}$ aliquots in a Waters 600 chromatograph equipped with a 600 controller pump and a Waters 431 conductivity detector. The $\mathrm{NO}_{3}^{-}$and $\mathrm{Cl}^{-}$concentrations in the electrolyzed solutions were determined using an IC-Pak AHR, $75 \mathrm{~mm} \times 4.6 \mathrm{~mm}$ (i.d.), anion column at $35{ }^{\circ} \mathrm{C}$ and a mobile phase of borate/gluconate at $1.0 \mathrm{~mL} \mathrm{~min}{ }^{-1}$. The $\mathrm{NH}_{4}^{+}$formation was determined with an IC-Pak C M/D, $150 \mathrm{~mm} \times 3.9 \mathrm{~mm}$ (i.d.) cation column at $25^{\circ} \mathrm{C}$ and $0.1 \mathrm{mM}$ EDTA $/ 3.0 \mathrm{mM} \mathrm{HNO}_{3}$ at $1.0 \mathrm{~mL} \mathrm{~min}^{-1}$ as mobile phase. 
2.4. Simultaneous degradation of pharmaceuticals.

Fantetra tablet weights of $4.10 \pm 0.11 \mathrm{~g}$ containing $0.50 \mathrm{~g}$ of OTC, $2.00 \mathrm{~g}$ of PhSTZ and $0.02 \mathrm{~g}$ of DPH were usede. Solutions of Fantetra were prepared dissolving $100 \mathrm{mg} \mathrm{L}^{-1}$ of tablet in $0.1 \mathrm{~L}$ of $0.1 \mathrm{M} \mathrm{Na}_{2} \mathrm{SO}_{4}$ at $\mathrm{pH}$ 7.0. The composition of the solution was $12.4 \mathrm{mg}$ of OTC, $49.5 \mathrm{mg}$ of PhSTZ and $1.2 \mathrm{mg}$ of DPH. Electrolysis were performed in the same system as was used for each separate drug. Moreover, a synthetic solution was prepared and electrolyzed adding the same quantities of each component in $0.1 \mathrm{~L}$ of electrolytic solution. The solution prepared in the laboratory will be called "Fantetra synthetic solution (FSS)", while the solution prepared from the commercial formulation will be called "commercial Fantetra solution (CFS)".

\section{RESULTS AND DISCUSSION}

3.1 Degradation and mineralization of each pharmaceutical separately.

The degradation and mineralization of OTC, PhSTZ and DPH was studied independently by electrochemical oxidation using a BDD/Steel plate system. Thus, solutions with $100 \mathrm{mg} \mathrm{L}^{-1}$ of each pharmaceutical were electrolyzed at initial $\mathrm{pH} 7.0$ with a current densisty of $50 \mathrm{~mA} \mathrm{~cm}{ }^{-2}$ during 3 hours. OTC shows a spectrum with two maxima at 277 and $360 \mathrm{~nm}$, which decay with electrolysis time as shown in Fig. 1a. At the end of the electrolysis the solution turne a slight pale yellow and the appearance of new bands were not detected under our experimental conditions. A similar trend was found for the degradation of $100 \mathrm{mg} \mathrm{L}^{-1}$ of PhSTZ (Fig. 1b), which has a maximum at $252 \mathrm{~nm}$ and decays by $60 \%$ after 3 hours of electrolysis. It is known that during the reaction of organic compounds with hydroxyl radicals, organic intermediates are generated, and they can absorb at the same wavelengths as the corresponding initial compounds. Chromatographic analysis showed that the chromatographic peak corresponding to PhSTZ disappeared completely after 60 min of electrolysis (inset in Figure 1b) and the formation of new peaks corresponding to oxidation products was observed. A different trend was seen in the case of DPH elimination. As can be seen in Fig. 1c, the initial spectrum presents a maximum at $260 \mathrm{~nm}$ which disappears completely after $10 \mathrm{~min}$ of electrolysis, and the absorption spectrum shows an increase in the absorbance at the same wavelength as the original compound. It is important to note that the spectrum generated does not match the original, showing that in a short time the compound has been completely degraded. Figure 2 a summarizes the above for the decay of the maximum absorbance of each compound. Thus, the decrease of the maximum absorbance for OTC reaches $95 \%$ after 150 minutes of electrolysis. For PhSTZ the absorbance at $252 \mathrm{~nm}$ decreased by about $60 \%$ after 3 hours of electrolysis. Something different is seen for DPH, since as noted, it showed a variation in the spectrum after $10 \mathrm{~min}$ of electrolysis with an increase in signal intensity at the same wavelength of the initial DPH. Thi new spectrum produced with greater intensity after $10 \mathrm{~min}$ of electrolysis, subsequently decays during the electrolysis. One possible explanation for this could be that the products or intermediates generated by the reaction between DPH and the hydroxyl radicals, having molar absorption coefficient greater than DPH, give rise to greater absorbance in the area of the main band, so it is possible to presume that the DPH is degraded in the first minutes of electrolysis.

The decay of the absorbance shows that pharmaceuticals are degraded independently by electrogenerated hydroxyl radicals. Thus, the abatement of total organic carbon (TOC) allows us to check if they are completely mineralized to $\mathrm{CO}_{2}$. In Fig. $2 b$, the decay of TOC is shown during electrolysis for each compound. In the same way of the decay of the maximum absorbance of the compounds, the TOC decreases with electrolysis time, confirming conversion to $\mathrm{CO}_{2}$. A complete mineralization of DPH $(>95 \%)$ was seen toward the end of the electrolysis, while $70 \%$ was obtained for PhSTZ mineralization and $65 \%$ for OTC. In the latter case it could be projected that at longer electrolysis time complete mineralization of the solution may be reached. However, during the electrolysis of PhSTZ and OTC, the starting compound was completely removed from the solution, therefore the TOC remaining in the solutions would correspond to the presence of organic intermediate or reaction products formed by attack of the hydroxyl radicals generated on the anode surface. Figure $2 \mathrm{c}$ shows the values of current efficiency for the mineralization process for each drug according to Eq. (3). The values obtained are close to $20 \%$, which is in agreement with results reported by other authors when POPs are electrolyzed using a system similar to that used in this work. ${ }^{10}$

On the other hand, the changes in the $\mathrm{pH}$ of the solutions at the end of electrolysis were to $7.26 \pm 0.11$ for an initial $\mathrm{pH}=7.0$. This result is an important finding in view of the future scaling-up of this technology in the treatment of water containing pharmaceuticals, because self-adjustment of $\mathrm{pH}$ simplifies the treatment and makes it more cost-affordable.

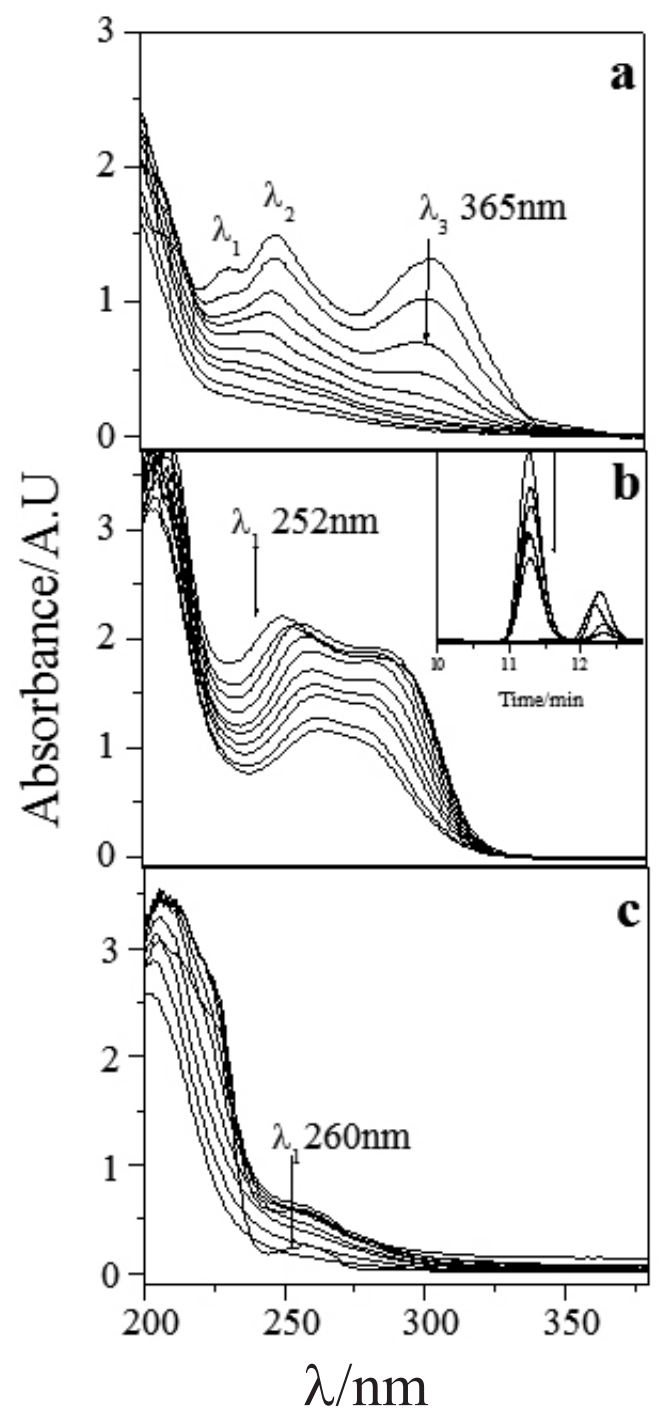

Figure 1. Spectra decay during the electrooxidation of $0.1 \mathrm{~L}^{\circ} 100 \mathrm{mg} \mathrm{L}^{-1}$ of (a) OTC, (b) PhSTZ and (c) DPH solutions in $0.1 \mathrm{M} \mathrm{Na}_{2} \mathrm{SO}_{4}$ at $35^{\circ} \mathrm{C}$ and $\mathrm{pH}$ 7.0 using the BDD/stainless steel system. Applied current density: $50 \mathrm{~mA} \mathrm{~cm}$ ${ }^{2}$. Inset in (b): chromatographic peak decay of PhSTZ during the electrolysis. Spectra were obtained every $20 \mathrm{~min}$.

Differences between absorbance and TOC decay of each compound were found, probably related to the different molecular structure of pharmaceuticals. Moreover, each pharmaceutical is eliminated before total organic carbon, showing the formation of organic intermediates from each compound, which are also rapidly destroyed by hydroxyl radicals, reaching a total decay of organic compounds to achieve complete mineralization, i.e., complete transformation into $\mathrm{CO}_{2}$ and $\mathrm{H}_{2} \mathrm{O}$. In this work, the main intermediaries detected during $\mathrm{EO}$ where carboxylic acids and inorganic ions.

3.2. Organic intermediates detected during EO of Fantetra components.

It is known that during the degradation of aromatic compounds, formation of short-linear carboxylic acids takes place, and then they are transformed into oxalic acid as ultimate product before the complete mineralization to $\mathrm{CO}_{2}{ }^{33}$ The carboxylic acids formed during the oxidation of the pharmaceutical studied were determined by liquid ion-exclusion chromatography. To identify each carboxylic acid seen in the chromatogram, samples of the most probable pure carboxylic acid and their mixtures were used as standards under the same experimental conditions. Thus, during the EO of OTC, oxalic, maleic, oxamic, fumaric and acetic acids were identified. Probably, fumaric and maleic acids come from the oxidation of the aryl moiety of the aromatics. The oxidation of these acids may generate acetic acid, while oxamic acid may be formed from 
the attack of $\mathrm{OH}$ on amine or amide groups. In the case of PhSTZ oxalic, maleic and oxamic acid were found. And for DPH formic, oxalic and oxamic acids were found. In all cases, at the end of the electrolysis, as expected, oxalic and oxamic acids are the last carboxylic acids that are directly transformed into $\mathrm{CO}_{2}{ }^{32}$

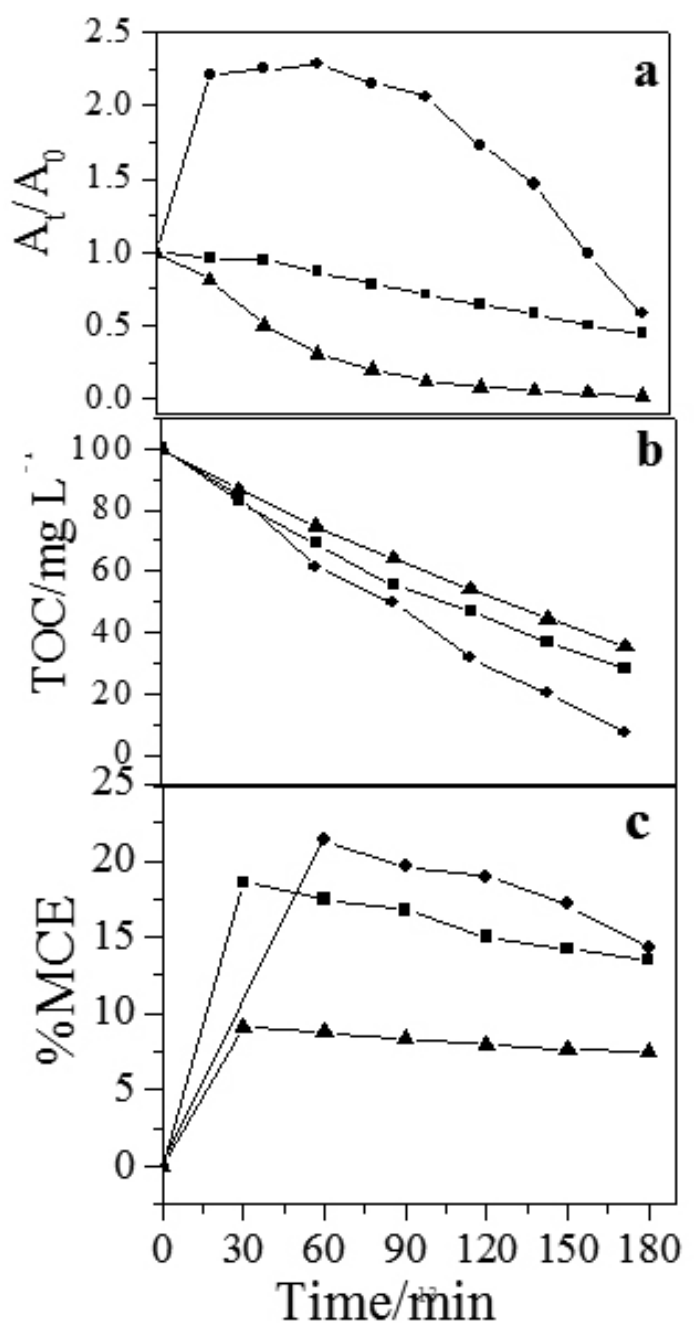

Figure 2. (a) Normalized absorbance at maximum wavelength; (b) TOC abatement; and (c) variation of mineralization current efficiency calculated from Eq. (3) vs. time for the electrooxidation of $0.1 \mathrm{~L}$ of $100 \mathrm{mg} \mathrm{L}^{-1}$ of $(\mathbf{\square})$ PhSTZ, ( $\Delta$ ) OTC and $(\bullet)$ DPH. Experimental conditions: $0.1 \mathrm{M} \mathrm{Na}_{2} \mathrm{SO}_{4}$ at $35^{\circ} \mathrm{C}$ and $\mathrm{pH} 7.0$, applying $50 \mathrm{~mA} \mathrm{~cm}{ }^{-2}$ using the $\mathrm{BDD} /$ stainless steel system. Data are the average of three independent experiments.

The determination of nitrogen requires the presence of inorganic cations or anions. It is very common to detect nitrogen compounds as $\mathrm{NH}_{4}^{+}$and $\mathrm{NO}_{3}$ ions in the mineralization of $N$-derivatives. ${ }^{34}$ The presence of these ions was followed by liquid ionic chromatography. The results indicate the presence of $\mathrm{NO}_{3}{ }^{-}$and $\mathrm{NH}_{4}^{+}$. At the end of the electrolysis, $\mathrm{NO}_{3}{ }^{-}$concentrations of 3.5 $\mathrm{ppm}$ for OTC, $1.2 \mathrm{ppm}$ for PhST and $0.8 \mathrm{ppm}$ for DPH were detected. The concentration of $\mathrm{NH}_{4}^{+}$at the end of electrolysis for the three compounds was lower than $0.5 \mathrm{ppm}$. Probably, the low $\mathrm{NH}_{4}^{+}$concentration detected at the end of the electrolysis of the pharmaceutical are due to the fact that the $\mathrm{pH}$ of the solution is slightly basic $(7.26 \pm 0.11)$. Final concentrations of $\mathrm{NO}^{-}$and $\mathrm{NH}_{+}^{+}$ ions detected at the end of the electrolysis correspond to $12.1 \%$ of initial $\mathrm{N}$ for OTC, $10.6 \%$ for PhST and $6.4 \%$ for DPH. Since the corresponding remaining oxamic acid only contains $1.0 \%$ of the initial $\mathrm{N}$, it can be inferred that a large fraction of the $\mathrm{N}$ of the initial molecules (ca. $3 \%$ ) is lost as volatile species, mainly as $\mathrm{N}_{2}$ and/or a $\mathrm{NO}_{x}$.
On the basis of the findings discussed above, the total mineralization of OTC, PhSTZ and DPH by EO is due to attack of $\mathrm{OH}$ that may be involved in the formation of aromatic intermediates which react with $\mathrm{OH}$ to produce a mixture of carboxylic acids together with $\mathrm{NO}_{3}^{-}$and $\mathrm{NH}_{4}^{+}$ions. The carboxylic acids continue reacting until they turn into oxalic acid, and subsequently into $\mathrm{CO}_{2}$ plus $\mathrm{H}_{2} \mathrm{O}$, while the initial pharmaceutical molecule, either OTC, PhSTZ or DPH, becomes completely mineralized according to equations (4-6).

3.3. Degradation of Fantetra from a prepared solution and from commercial formulation.

Finally, the method of electro-oxidation was applied for the simultaneous degradation of the three drugs in the Fantetra commercial tablet. Fig. 3a shows the spectra for each drug. As can be seen, only the absorbance of PhSTZ and OTC are well defined to be analyzed at the wavelengths mentioned in the previous sections. The case of DPH is different, because it has a band that is within the overall spectrum, but with a much lower absorbance than that of the other two compounds present in the formulation, and therefore it cannot be evaluated spectrophotometrically in the mixture.

Solutions of $100 \mathrm{ppm}$ of the pharmaceutical formulation of Fantetra were degraded in water under the same experimental conditions at which each drug was degraded independently. Furthermore, solutions containing the three compounds in the same proportions as present in the commercial pharmaceutical formulation of Fantetra were prepared and degraded as mentioned before. The spectra corresponding to the degradation of both solutions for $3 \mathrm{~h}$ of electrolysis are shown in Figures $3 b$ and 3c, respectively.

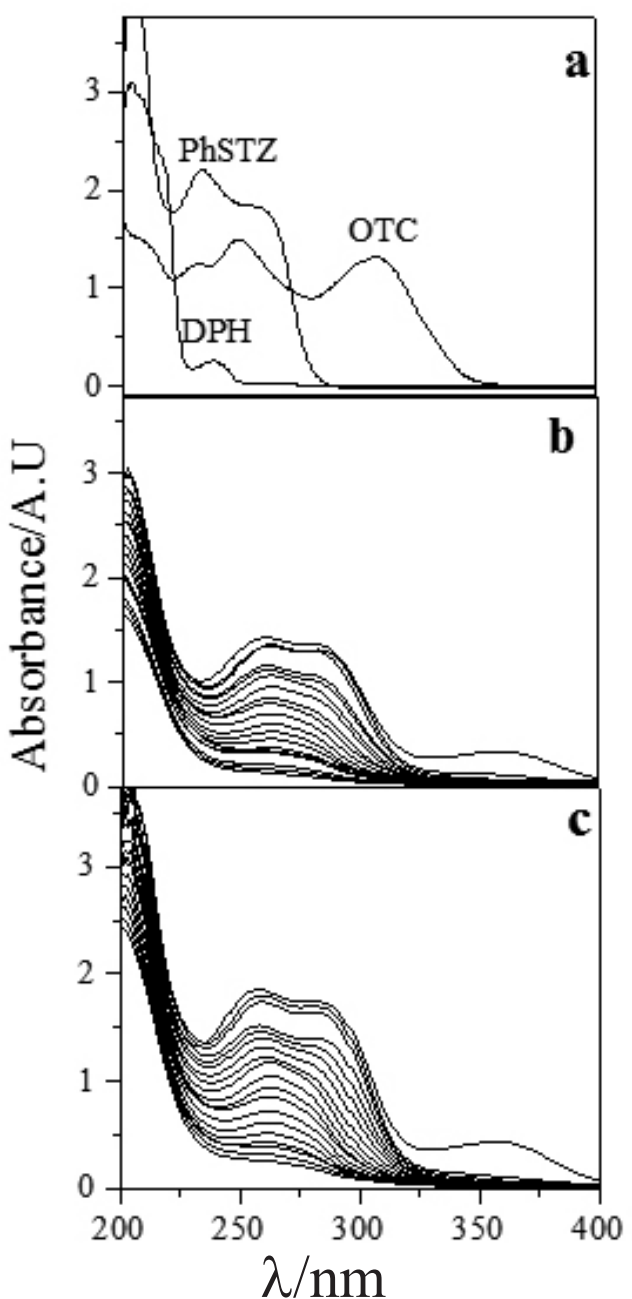

Figure 3. (a) Spectra of $100 \mathrm{mg} \mathrm{L}^{-1}$ of each component of Fantetra; (b) spectra decay during the electrooxidation of $0.1 \mathrm{~L}$ of $100 \mathrm{mg} \mathrm{L}^{-1} \mathrm{of} \mathrm{FSS}$; and (c) CFS solutions in $0.1 \mathrm{M} \mathrm{Na}_{2} \mathrm{SO}_{4}$ at $35^{\circ} \mathrm{C}$ and $\mathrm{pH} 7.0$ using the $\mathrm{BDD} /$ stainless steel system. Applied current density: $50 \mathrm{~mA} \mathrm{~cm}^{-2}$. 
It was found that for both mixtures, FSS (Fig. 3b) and CFS (Fig. 3c), bands corresponding to both OTC and PhSTZ decay during electrolysis. These results allow us to conclude that the method is applicable to the removal of both drugs from waters containing them, under the experimental conditions employed. In both cases it is seen that the band at $360 \mathrm{~nm}$ corresponding to OTC decays completely after the first 10 minutes of electrolysis. The bands in the range of 250-300 $\mathrm{nm}$ associated with OTC and PhSTZ decay gradually during electrolysis, reaching a value close to zero at the end of the process. The difference between the FSS and CFS solutions is the presence of excipients in CFS (Table 2). As can be seen in Figs. 3 a and b, commercial tablets do not show a significant difference when analyzing the decay of the absorbance of each component of the mixture. In both cases, complete elimination of TOC is achieved after 3 hours of electrolysis (Table 2).

Table 2. Composition of $100 \mathrm{mg} \mathrm{L}^{-1}$ of FSS and CFS and total organic carbon before and after the electro-oxidation treatment. Experimental conditions: $0.1 \mathrm{M} \mathrm{Na}_{2} \mathrm{SO}_{4}$ at $35^{\circ} \mathrm{C}$ and $\mathrm{pH} 7.0$ applying $50 \mathrm{~mA} \mathrm{~cm}{ }^{-2}$ using the $\mathrm{BDD} /$ stainless steel system. Data are the average of three independent experiments.

\begin{tabular}{|c|c|c|c|c|c|c|}
\hline \multicolumn{4}{|c|}{ Composition $\left(\mathrm{mg} \mathrm{L}^{-1}\right)$} & \multicolumn{2}{c|}{ TOC $\left(\mathrm{mg} \mathrm{L}^{-1}\right)$} & \\
\hline Solution & PhSTZ & DPH & OTC & Excipients & Initial & Final \\
\hline CFS & 49.5 & 1.2 & 12.4 & 0.037 & 36.0 & 2.8 \\
\hline FSS & 49.2 & 1.3 & 12.2 & - & 24.0 & 2.7 \\
\hline
\end{tabular}

\section{CONCLUSIONS}

OTC, PhSTZ and DPH could be degraded by EO with the generation of hydroxyl radicals on the anode surface, reaching $>70 \%$ of mineralization for each compound separately. On the other hand, complete degradation and mineralization is obtained for solution containing $100 \mathrm{mg} \mathrm{L}-1$ of Fantetra in solutions prepared from each drug or from the commercial formulation. Finally, the mineralization process of Fantetra components by EO generates organic intermediates as carboxylic acids (oxalic, oxamic, maleic, acetic), ammonia and nitrate ions before their complete transformation into $\mathrm{CO}_{2}$.

\section{ACKNOWLEDGMENTS}

Financial support of FONDECYT under Project 1130391 and DICYTUSACH is gratefully acknowledged.

\section{REFERENCES}

1 J. Rivera-Utrilla, M. Sánchez-Polo, M.A. Ferro-García, G. Prados-Joya, R. Ocampo-Pérez. Chemosphere 93, 1268, (2013).

2 I. Arslan-Alaton, T. Olmez-Hanci. New and Future Developments in Catalysis. Catalysis for Remediation and Environmental Concerns. Chapter 12 - Sources of Environmental Pollution: Persistent Organic Pollutants. Elsevier, 2013, pp 303-398.

3 G. Mascolo, L. Balest, D. Cassano, G. Laera, A. Lopez, A. Pollice, C. Salerno. Bioresource Technol 101, 2585, (2010).

4 O.A. Jones, J.N. Lester, N. Voulvoulis, Trends in Biotechnol 23, 163, (2005).
5 D.I. Andersson, D. Hughes. Drug Resistance Updates 15, 162, (2012).

6 M. Klavarioti, D. Mantzavinos, D. Kassinos. Environ. Int. 35, 402, (2009)

7 C.A. Martínez-Huitle, E. Brillas. Appl Catalysis B: Environ 87, 105, (2009).

8 Ch. Comninellis, G. Chen. Electrochemistry for the Environment. 1st ed. New York. Springer, 2009, pp.1-23.

9 M. Panizza, A. Kapalka, Ch. Comninellis. Electrochim. Acta 53, 2289 , (2008).

10 J. Urzúa, C. González-Vargas, F. Sepúlveda, M.S. Ureta-Zañartu, R. Salazar. Chemosphere 93, 2774, (2013).

11 R. Salazar, M.S. Ureta-Zañartu. Water Air Soil Pollut. 223, 4199, (2012).

12 M. Panizza, G. Cerisola. Water Res. 43, 339, (2009).

13 P.A. Carneiro, M.E. Osugi, J.J. Sene, M.A. Anderson, M. Valnice, B. Zanoni. Electrochim. Acta 49, 3807, (2004).

14 R. Salazar, M.S Ureta, J. Chil. Chem. Soc. 57, 999, (2012).

15 S. Garcia-Segura, R. Salazar, E. Brillas. Electrochim. Acta 113, 609, (2013).

16 R. Salazar, E. Brillas, I. Sirés. Appl. Catalysis B: Environ. 115- 116, 107, (2012).

17 Jong Young Choia, You-Jin Leea, Jina Shina, Ji-Won Yanga. J. Hazard. Mat. 179, 762, (2010).

18 C.I. Brinzila, M.J. Pacheco, L. Ciríaco, R.C. Ciobanu, A. Lopes. Chem. Eng. J. 209, 54, (2012).

19 E. Tsantaki, T. Velegraki, A. Katsaounis, D. Mantzavinos. J. Hazard. Mat. 207-208, 91, (2012).

20 M. Panizza, G. Cerisola. Electrochim. Acta 48, 3491, (2003).

21 M. Panizza, G. Cerisola. Electrochim. Acta 51, 191, (2005).

22 E. Guinea, F. Centellas, E. Brillas, P. Cañizares, C. Sáez, M.A. Rodrigo. Appl Catalysis B: Environ 89, 645, (2009).

23 C.A. Martinez-Huitle, E. Vieira dos Santos, D. Medeiros de Araujo, M. Panizza. J. Electroanal. Chem. 674, 103, (2012).

24 Ministerio de agricultura de Chile. Medicamentos veterinarios autorizados por el Servicio Agrónomo y ganadero, SAG

25 X.Liang, Z.Wang, C. Wang, K. Wen, T. Mi, J. Zhang, S. Zhang. Anal. Biochem. 438, 110, (2013).

26 S.M. Miller, K.L. Cumpston. Encyclopedia of Toxicology (Third Edition), 2014, pp 195-197.

27 K. Li, A. Yediler, M.Yang, S. Schulte-Hostede, M. Hung Wong. Chemosphere 72, 473, (2008).

28 L. M. Pastrana-Martínez, J.L. Faria, J.M. Doña-Rodríguez, C. FernándezRodríguez, A. Silva. Appl Catalysis B: Environ 113- 114, 221, (2012).

29 M. Velázquez, I. P. Santander, D.R. Contreras, J. Yáñez, C. Zaror, R.A. Salazar, M. Pérez-Moya, H.D. Mansilla. Journal of Environmental Science and Health, Part A 49, 661, (2014).

30 S. Morales-Torres, L.M. Pastrana-Martínez, J.L. Figueiredo, J.L. Faria, A. Silva. Appl. Surf. Sci. 275, 361, (2013).

31 R. Salazar, S. Garcia-Segura, M.S. Ureta-Zañartu, E. Brillas. Electrochim. Acta 56, 6371, (2011).

32 M. Skoumal, C. Arias, P. L. Cabot, F. Centellas, J.A. Garrido, R. M. Rodriguez, E. Brillas

Chemosphere 71, 1718, (2008).

33 S. Garcia-Segura, E. Brillas. Water Res. 45, 2975, (2011).

34 M. Hamza, R. Abdelhedi, E. Brillas, I. Sires. J. Electroanal. Chem. 627, $41,(2009)$. 